\title{
Fruit from the Sands: The Silk Road Origins of the Foods We Eat. By Robert N. Spengler III. 2019. University of California Press, Berkeley. $392 \mathrm{pp}$.
}

\author{
Eugene N. Anderson ${ }^{1 *}$ \\ ${ }^{1}$ Department of Anthropology, University of California, Riverside, USA. \\ gene@ucr.edu
}

Received August 9, 2019

OPEN ठ ACCESS

Accepted November 8, 2019

Published December 4, 2019

DOI 10.14237/ebl.10.1.2019.1636

Copyright (c) 2019 by the author(s); licensee Society of Ethnobiology. This is an open-access article distributed under the terms of the Creative Commons Attribution-NonCommercial 4.0 International Public License (https://creativecommons.org/licenses/by-nc/4.0), which permits non-commercial use, distribution, and reproduction in any medium, provided the original author and source are credited.

Writings in English on central Asian food have tended to emphasize meat and dairy, because of the romantic identification of the region with herders and nomads. Yet central Asia has an ancient and highly developed agricultural sector, and was the source of apples, apricots, and other plants, including varieties of carrots, melons, and nuts. Robert Spengler, a young archaeobotanist with much experience in the region, has produced an excellent guide to the plant foods and their history. He personally excavated and identified many of the remains he describes. The book focuses on genetics and archaeology, but also covers history, as well as modern production. Sections cover grains, legumes, grapes and apples, other fruits and nuts, vegetables, spices, oils, and tea.

The book begins with a description of central Asia and its plants, quoting many Arab geographers as well as European explorers. Spengler points out that "Until the first millennium BC, much of southern Central Asia was a lush expanse of short, shrubby forest, which included wild pistachio, almond, cherry. ...The piedmont of Central Asia was once covered in forests of sea buckthorn (Hippophae rbamnoides)..." (pp. 12-13) and other fruit trees. Emphasized also is the role of irrigation, always important, but developed in the medieval period to an extremely high standard, with innovations now used worldwide.

The first plant discussed is broomcorn millet, which spread slowly from China, where it was domesticated around 6000 BCE; by 2000 BCE, it had reached Europe. Long unsung, it was the staple food in eastern Europe and much of central Asia throughout early history. At some obscure but quite recent time, it was replaced by rye in eastern Europe-a major agricultural revolution that seems to have gone little noticed, though tax and farm rolls from tsarist Russia would surely reveal the details. High-yield, heat-adapted wheats replaced it in central Asia quite recently. Spengler provides up-to-date information on the genetics, origins, and spread of both broomcorn and foxtail millet, as well as rice, wheat, and barley. Foxtail millet never amounted to much in central Asia; it needs China's hotter, wetter climate. Rice, however, was grown where there was warmth and ample water, though that limited it to a few river valleys.

Apples originated in what is now eastern Kazakhstan, near the city of Almaty, formerly AlmaAta, "father of apples." The name commemorates a local Johnny Appleseed, though, not the original domestication events. Once again, genetics, origin, and spread are well described. Apricots originated in central Asia, somewhere between Turkey and China-wild ones are widespread. Wine grapes, originally from the east Black Sea coastal areas, spread and flourished. Most of the common fruits and nuts of the Near East and eastern Europe became established and important. Central Asia's oasis cities today consume incredible quantities of them. Stall after stall in any market is taken up with dried ones, and fresh ones in season. One wonders how even cities of a million or more could eat so many strawberries, cherries, apricots, and the rest. Tashkent 
has so many fruit trees planted as yard and street trees that it is almost a food forest. No one seems to mind the staining of pavement and cars by the thousands of mulberry trees that drop varicolored fruit in May. Quite the reverse; the trees develop a pronounced browse line at the height of an average person's reach.

Spices are less abundant and important, but the Silk Road (or Silk Routes-there were parallel tracks) was as important for them as it was for silk. Tons of spices and medicinals - originally the same categorytraveled by camel across the vast deserts, sky-reaching mountains, and lush oases. Almost half a century ago, I watched a camel caravan crossing an 11,000-foot pass in Afghanistan, an impressive sight. Such was trade until very recently.

There are a few errors in this book. The most obvious, unfortunately and mistakenly cited to me, translates the Chinese word fan as "rice" (p. 89). Fan means any cooked grain used as a staple food or substrate for other food (made dishes, car). In south China, fan is virtually synonymous with cooked rice, but rice has its own species name, dao, and fan originally applied largely to cooked millet. Another error occurs on p. 13, where those fruit forests are said to have given way to "lizards, snakes, and desert saxaul trees (Haloxylon)." This is not the case. Saxaul grows in the hottest, driest deserts, where fruit and nut trees do not survive. Far from replacing food
Perspectives from Gene Anderson's bookshelf

trees, saxaul is itself threatened, by firewood cutting and the like. What has replaced the fruit and nut groves is rough grazing. The forests have been cleared, mostly long since the first millennium, for pasture. I have seen isolated fruit trees standing in otherwise sheep-cropped grass in several central Asian countries. One more error worth noting is the idea that the Chinese word usually translated "wine" really means, basically, grape wine (p. 262). Jiu has always meant any sort of alcoholic liquid. For the first few thousand years of its career as a word, it meant ale, mostly made from millet. Grape wine reached China around 2000 years ago, and was duly called "grape jiu." Similarly for other liquors, and even for medicinal alcohol; tincture of iodine is "iodine jiu."

Aside from these points, the book is highly scientific and accurate, and very valuable. It corrects the imbalance of lore in western food literatures, and brings to the world an extremely rich and productive agricultural tradition. The photographs, largely taken by the author, are revealing and important. Robert Spengler was a student of Michael Frachetti and the Society of Ethnobiology's former editor Naomi Miller, and his work is top-flight archaeobotany. 